https://doi.org/10.15407/ujpe64.1.56

P.O. SAI ${ }^{1,2}$ N.V. SAFRYUK-ROMANENKO,${ }^{1}$ D.B. BUT, ${ }^{1,2}$ G. CYWIŃSKI, ${ }^{2}$ N.S. BOLTOVETS,${ }^{3}$ P.N. BRUNKOV,${ }^{4}$ N.V. JMERIC, ${ }^{4}$ S.V. IVANOV,${ }^{4}$ V.V. SHYNKARENKO ${ }^{1}$

${ }^{1}$ Lashkaryov Institute of Semiconductor Physics, Nat. Acad. of Sci. of Ukraine (41, Prosp. Nauky, Kyiv 03680, Ukraine)

2 Center for Terahertz Research and Applications (CENTERA), Institute of High Pressure Physics of the PAS (29/37, Ul. Sokolowska, 01-142, Warsaw, Poland)

3 State Enterprise Research Institute "Orion" (8a, E. Pottier Str., Kyiv 0305\%, Ukraine)

${ }^{4}$ A. Ioffe Physicotechnical Institute, Russian Academy of Sciences (26, Politekhnicheskaya Str., St. Petersburg 194021, Russia)

\title{
FEATURES OF THE FORMATION OF OHMIC CONTACTS TO ${ }^{+}-$InN
}

\section{Introduction}

The experimentally confirmed electron transport properties of indium nitride attract a great attention among III-nitride group materials. Recently, it was

(C) P.O. SAI, N.V. SAFRYUK-ROMANENKO, D.B. BUT, G. CYWIŃSKI, N.S. BOLTOVETS, P.N. BRUNKOV, N.V. JMERIC, S.V. IVANOV, V.V. SHYNKARENKO, 2019
We report about a study of the formation and current transport mechanism of ohmic contacts to $n^{+}-$InN with electron concentrations of $2 \times 10^{18}, 8 \times 10^{18}$, and $4 \times 10^{19} \mathrm{~cm}^{-3} . \mathrm{Pd} / \mathrm{Ti} / \mathrm{Au}$ ohmic contacts are formed by the proposed approach of simultaneous magnetron metal deposition and in-situ temperature annealing, which allows obtaining a low contact resistivity $(4.20 \pm 2.67) \times 10^{-6} \mathrm{Ohm} \cdot \mathrm{cm}^{2}$. The additional rapid thermal annealing in the temperature interval $350-400^{\circ} \mathrm{C}$ is used to improve further contact characteristics. Optimal parameters of the temperature treatment are determined by statistic methods. As for the current transport mechanism, the unusual growing temperature behavior of contact resistivity is observed in the wide temperature range 4.2-380 K for each doping level of InN films. The mechanism of thermionic current flow explains the current transport through metal shunts, which is associated with the conducting dislocations. The extracted density of conducting metal shunts has a good agreement with experimental values of the screw and edge dislocation densities experimentally obtained by high-resolution X-ray diffraction. Additionally, from the obtained contact resistivity temperature dependences, we can argue about the metal, which penetrates dislocations and forms shunts.

Keywords: ohmic contacts, rapid thermal annealing, in-situ thermal annealing, contact resistivity, dislocation density, metal shunts.

reported Ref. [1] about the highest achieved value of electron mobility $3500 \mathrm{~cm}^{2} / \mathrm{Vs}$ at room temperature for this material, and a maximum of the $\mathrm{InN}$ mobility of $14000 \mathrm{~cm}^{2} / \mathrm{Vs}$ was theoretically predicted in Ref. [2] for samples with low carrier concentrations. In addition, the $\mathrm{InN}$ drift velocity in the range $5 \times 10^{7}-2 \times 10^{8} \mathrm{~cm} / \mathrm{s}$ was demonstrated by Ref. [3] at room temperature. These remarkable features make InN a promising material firstly for high-speed elec-

ISSN 2071-0194. Ukr. J. Phys. 2019. Vol. 64, No. 1 
Table 1. Q-factors for high-frequency

transistors evaluated on the basis of electrical semiconductor parameters [8,9]

\begin{tabular}{|c|c|c|c|c|c|c|}
\hline $\begin{array}{c}\text { Parameters } \\
\text { at } 300 \mathrm{~K}\end{array}$ & $\begin{array}{c}\text { InN } \\
\text { (wurtzite) }\end{array}$ & $\begin{array}{c}\text { AIN } \\
\text { (wurtzite) }\end{array}$ & $\begin{array}{c}\text { GaN } \\
\text { (wurtzite) }\end{array}$ & $\begin{array}{c}\mathrm{GaN} \\
\text { (zinc bland) }\end{array}$ & $\begin{array}{c}\text { GaAs } \\
\text { (zinc bland) }\end{array}$ & $\begin{array}{c}\mathrm{Si} \\
\text { (diamond) }\end{array}$ \\
\hline $\begin{array}{l}\text { Cutoff frequency [4] } \\
f_{t}=\frac{\nu_{s}}{2 \pi L_{G}}, \times 10^{12} \mathrm{~s}^{-1} \\
\text { Keyes' Q-factor [5] }\end{array}$ & 3.18 & 0.27 & 0.51 & 0.51 & 0.32 & 0.16 \\
\hline $\begin{array}{l}\mathrm{KFOM}=\chi \sqrt{\frac{c \nu_{s}}{4 \pi \varepsilon_{s}}}, \times 10^{6} \mathrm{~W} /(\mathrm{K} \cdot \mathrm{s}) \\
\text { Baliga's Q-factor [6] }\end{array}$ & 88.3 & 70.6 & 112.9 & 111.7 & 28.1 & 67.5 \\
\hline $\mathrm{BFOM}=\varepsilon_{s} \mu E_{g}^{3}, \mathrm{~m}^{2} \mathrm{eV}^{3} /(\mathrm{V} \cdot \mathrm{s})$ & 1.8 & 238.6 & 52.0 & 34.9 & 16.7 & 2.2 \\
\hline Band gap $E_{g}, \mathrm{eV}$ & $0.70[10]$ & 6.20 & 3.51 & 3.30 & 1.42 & 1.12 \\
\hline Effective electron mass, $m_{\mathrm{eff}}$ & 0.04 & 0.40 & 0.20 & 0.13 & 0.06 & 0.19 \\
\hline Mobility of electrons $\mu, \mathrm{cm}^{2} /(\mathrm{V} \cdot \mathrm{s})$ & $3500[1]$ & 1100 & 1300 & 1000 & 6000 & 1350 \\
\hline Drift velocity $v_{s}, \times 10^{7} \mathrm{~cm} / \mathrm{s}$ & $20.0[3]$ & 1.9 & 3.0 & 3.0 & 2.0 & 1.0 \\
\hline Thermal conductivity $\chi, \mathrm{W} /(\mathrm{cm} \cdot \mathrm{K})$ & 0.5 & 1.0 & 1.3 & 1.3 & 0.4 & 1.5 \\
\hline Dielectric constant $\varepsilon_{s}$ & 15.3 & 9.1 & $8.9-9.5$ & 9.7 & 9.7 & 11.8 \\
\hline
\end{tabular}

tronic devices, that was also confirmed by evaluated Q-factors for high-frequency transistors [4] with gate length equals to $0.1 \mu \mathrm{m}$ (see Tabl. 1). The highest cut-off frequency was obtained for transistors based on InN. Other criteria in case of $\mathrm{InN}$ are comparable to GaAs Q-factors; there are Keyes' Qfactor [5] that provides a thermal limitation to the switching behavior of transistors and Baliga's Qfactor [6], which defines material parameters to minimize the conduction loss in low-frequency unipolar transistors.

The critical problem of InN-based electronics devices is a high defect density in thin films due to the absence of homogeneous bulk substrates. Nowadays, the growth processes of InN epitaxial structures use substrates like sapphire, silicon, or silicon carbide in most cases. The mismatches of lattice parameters and thermal coefficients are $+11 \%$ and $-38 \%$, respectively, even with using GaN buffer layers. As a result, InN layers have a high density of dislocations in the range from $10^{9}$ to $10^{11} \mathrm{~cm}^{-2}$ [7].

In its turn, a high structural defect density affects, to the greatest extent, the process of formation of ohmic contacts as built-in elements of any semiconductor devices including high-frequency transistors. Features of the ohmic contact formation and a current transport mechanism through the "metalInN" interface and its explanation are the main goals of the present work.

ISSN 2071-0194. Ukr. J. Phys. 2019. Vol. 64, No. 1

\section{Fabrication of Samples and Investigation Methods}

InN films were grown on the $\mathrm{Al}_{2} \mathrm{O}_{3}$ substrate with a $0.9 \mu \mathrm{m}$ GaN buffer layer by plasma-assisted molecular beam epitaxy (PAMBE). The doping level of the $\mathrm{InN}$ films was $4 \times 10^{19} \mathrm{~cm}^{-3}$ (sample A), $8 \times 10^{18} \mathrm{~cm}^{-3}$ (samples B), and $2 \times 10^{18} \mathrm{~cm}^{-3}$ (samples C). Ohmic contacts were formed by the sequential magnetron sputtering of $\mathrm{Pd}(30 \mathrm{~nm}) / \mathrm{Ti}(50 \mathrm{~nm}) / \mathrm{Au}(100 \mathrm{~nm})$ onto the InN epitaxial films, by using the $i n$-situ thermal annealing at $350{ }^{\circ} \mathrm{C}$. The metallization of multilayers according to principles of the formation of ohmic contacts was described in Ref. [11], Pd was used as the contact formation layer, the following layer of $\mathrm{Ti}$ was deposited to prevent the diffusion process and is known as an antidiffusion barrier, and $\mathrm{Au}$ was the last layer. The samples were patterned by a lift-off process, and contact resistivities were measured using the Transition Line Method (TLM). A more detailed information about the preparation of samples can be found in Refs. [12, 13]. Samples A and $\mathrm{B}$ (see Tabl. 2) were additionally annealed at $350-400{ }^{\circ} \mathrm{C}$ for $2 \mathrm{~min}$ in a rapid thermal annealing (RTA) furnace. The contact resistivity $\left(\rho_{\mathrm{c}}\right)$ as an essential parameter of the ohmic contact quality was measured by TLM before and after RTA. Additionally, the contact resistivity temperature dependences $\rho_{\mathrm{c}}(T)$ for an explanation of the current 
Table 2. Structure parameters of the investigated samples obtained by HRXRD

\begin{tabular}{|c|c|c|c|c|c|}
\hline Sample & $\begin{array}{c}\text { Doping level, } N_{d} \\
{\left[\mathrm{~cm}^{-3}\right]}\end{array}$ & Treatment & $\begin{array}{c}\text { Thickness of } \\
\text { InN layer, } D \\
{[\mu \mathrm{m}]}\end{array}$ & $\begin{array}{c}\text { Screw dislocation } \\
\text { density, } N_{s} \times 10^{8} \\
{\left[\mathrm{~cm}^{-2}\right]}\end{array}$ & $\begin{array}{c}\text { Edge dislocation } \\
\text { density, } N_{E} \times 10^{9} \\
{\left[\mathrm{~cm}^{-2}\right]}\end{array}$ \\
\hline $\mathrm{A}$ & $\begin{array}{l}4 \times 10^{19} \\
4 \times 10^{19}\end{array}$ & $\begin{array}{l}- \\
\text { RTA } 370^{\circ} \mathrm{C}\end{array}$ & $\begin{array}{l}0.9 \\
0.9\end{array}$ & $\begin{array}{l}46.37 \\
26.12\end{array}$ & $\begin{array}{l}25.70 \\
22.80\end{array}$ \\
\hline B & $\begin{array}{l}8 \times 10^{18} \\
8 \times 10^{18}\end{array}$ & ${ }^{-}{ }^{-}{ }^{\circ} 400^{\circ} \mathrm{C}$ & $\begin{array}{l}2.5 \\
2.5\end{array}$ & $\begin{array}{l}2.77 \\
2.91\end{array}$ & $\begin{array}{l}5.35 \\
8.90\end{array}$ \\
\hline $\mathrm{C}$ & $2 \times 10^{18}$ & - & 0.6 & 2.30 & 3.40 \\
\hline
\end{tabular}

transport mechanism were measured in the range $4.2-380 \mathrm{~K}$.

High-Resolution X-Ray Diffraction (HRXRD) was used for the determination of structural parameters of InN epitaxial films. We analyzed both the symmetric and asymmetric reflections of $\mathrm{InN}$ and GaN films. The Williamson-Hall plots were used for the analysis of dislocation densities (both types: screw $N_{S}$ and edge $N_{E}$ ). Results of HRXRD studies are shown in Tabl. 2.

\section{Results and Discussion}

Ohmic contacts were formed currently after the metal deposition onto in-situ heated semiconductor films. Linearity and symmetry of $\mathrm{I}-\mathrm{V}$ characteristics confirmed the ohmicity of contacts. The mean value of contact resistivity obtained from TLM measurements with $95 \%$ confidence intervals was (4.20 \pm $2.67) \times 10^{-6} \mathrm{Ohm} \cdot \mathrm{cm}^{2}$ for $\mathrm{C}$ sample. According to Ref. [14], we achieved a low contact resistivity in case of the $2 \times 10^{18} \mathrm{~cm}^{-3}$ doping level directly after the single technological process of metal deposition without any additional treatments.

In cases of $\mathrm{A}$ and $\mathrm{B}$ samples with higher doping levels, $\rho_{\mathrm{c}}=(2.99 \pm 1.41) \times 10^{-4}$ and $(1.18 \pm 1.34) \times$ $\times 10^{-3} \mathrm{Ohm} \cdot \mathrm{cm}^{2}$, respectively (Fig. 1, a, b). These $\rho_{\mathrm{c}}$ values are high in comparison to reported results for similar doping levels [14]. To improve the electrical characteristics of ohmic contacts, the additional RTA was provided at $350-400{ }^{\circ} \mathrm{C}$ with a duration of 2-8 min. In case of sample $\mathrm{B}$, the optimal parameters of RTA were $370{ }^{\circ} \mathrm{C}$ and 2 min according to the histograms of contact resistivity distributions (Fig. 1, $a$, $c, e, g)$, when the minimal mean value of $\rho_{\mathrm{c}}$ was obtained. In addition, a considerable reduction of the $\rho_{\mathrm{c}}$ dispersion was observed in the RTA process. It should be noted that the contact resistivity is described by a lognormal distribution, since this physical value is defined by an exponential expression including the barrier height as a normal random variable.

For sample A, we decided to use RTA $350-370{ }^{\circ} \mathrm{C}$, but the last RTA process had increased the duration to $8 \mathrm{~min}$. The mean contact resistivity was significantly reduced by about two orders of magnitude after the additional RTA $370{ }^{\circ} \mathrm{C}$ (Fig. 1, f). Increasing the RTA duration to $8 \mathrm{~min}$ allows minimizing the contact resistivity dispersion (Fig. $1, h$ ).

According to the HRXRD results (see Tabl. 2), the ohmic contacts to InN films had a high density of dislocations of both types: edge and screw. However, the dislocation densities of both types were slightly reduced after the RTA process in the case of sample A. Total values of dislocation densities were $2.5 \times 10^{10}$, $9.2 \times 10^{9}$, and $3.6 \times 10^{9} \mathrm{~cm}^{-2}$, respectively, for samples $\mathrm{A}, \mathrm{B}$, and $\mathrm{C}$.

The essential diffusion of $\mathrm{Pd}$ into the $\mathrm{InN}$ layer was observed for sample C (Fig. 2, c). In contrast to that, a significant accumulation of indium near the interface "metal-InN" was confirmed by Auger profiling (Fig. 2, $a, b$ ) for samples A and B. As a possible cause for such accumulation is the specificity of InN epitaxial growth, as it was discussed in Ref. [15]. The signal attributed to nitrogen was not registered in this region. Thus, there is a high probability of the influence of such accumulation on the process of formation of ohmic contacts.

The temperature dependence of the contact resistivity $\rho_{\mathrm{c}}(T)$ was measured to clarify a current transport mechanism through the "metal-InN" interface. We measured $\rho_{\mathrm{c}}(T)$ in the range from 4.2 to $380 \mathrm{~K}$ (Fig. 3) for each sample. The value of $\rho_{\mathrm{c}}(T)$ increases with the temperature; such behavior is es- 


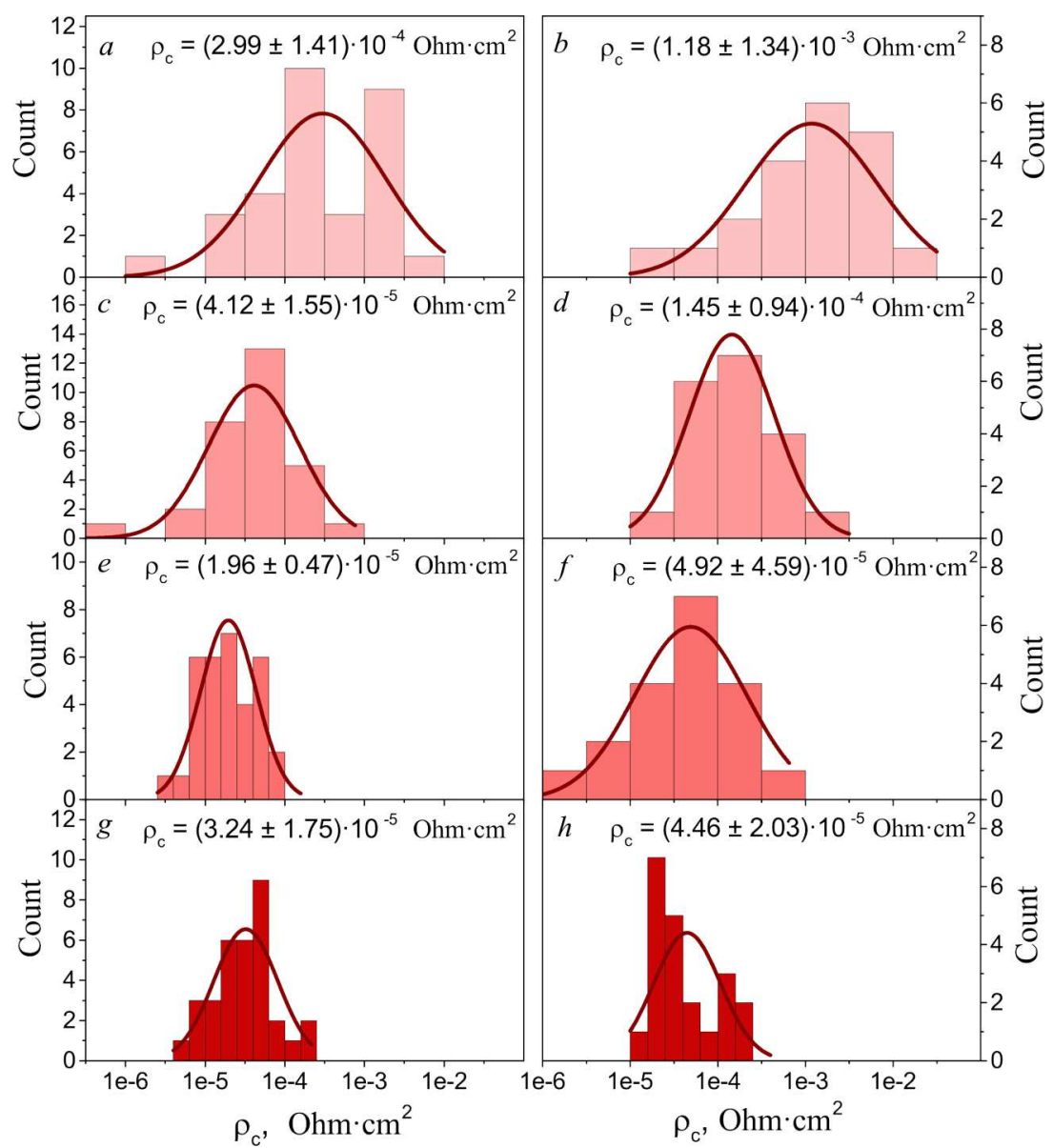

Fig. 1. Contact resistivity distributions of sample $\mathrm{B}(a, c, e, g)$ and sample $\mathrm{A}(b$, $d, f, h)$ after the in-situ annealing $(a, b)$, RTA $350{ }^{\circ} \mathrm{C}$ for 2 min $(c, d)$, RTA $370{ }^{\circ} \mathrm{C}$ for $2 \min (e, f)$, RTA $400{ }^{\circ} \mathrm{C}$ for $2 \min (g)$, and RTA $370{ }^{\circ} \mathrm{C}$ for $8 \min (h)$

sentially different from the typical behavior of "metalsemiconductor" contacts with classical current transport mechanisms: the thermo-field and thermionic emissions ( $\rho_{\mathrm{c}}$ decreases with temperature) or tunneling ( $\rho_{\mathrm{c}}$ does not depend on the temperature). The direct use of the classical current transport mechanisms cannot explain our results on a current transport through the "metal-InN" interface.

Goldberg et al. in Ref. [16] firstly investigated the growing temperature dependence $\rho_{\mathrm{c}}(T)$ of ohmic contacts to $\mathrm{GaP}$ and proposed an explanation, by using the temperature dependence of the metal shunt resistance. The metal shunts at an ohmic contact are associated with threading dislocations and are formed during the process of ohmic contact fabrication. The first report on the current transport mechanism through ohmic contacts to InN was presented by Ref. [17] in a wide range of temperature $4.2-400 \mathrm{~K}$, where the growing $\rho_{\mathrm{c}}(T)$ dependences were also observed. However, the proposed explanation by the metallic type of InN does not describe the behavior in the low-temperature range $4.2-150 \mathrm{~K}$.

We propose an explanation of the unusual behavior of ohmic contacts considering the current transport through the metal shunts along the dislocations and include the current limitation by a diffusion mechanism of supplying electrons. The consideration of the current flows through the regions accumulating electrons rather than depleted regions is the essential difference from the model developed in Ref. [7]. The electron-enriched regions are formed due to a high 

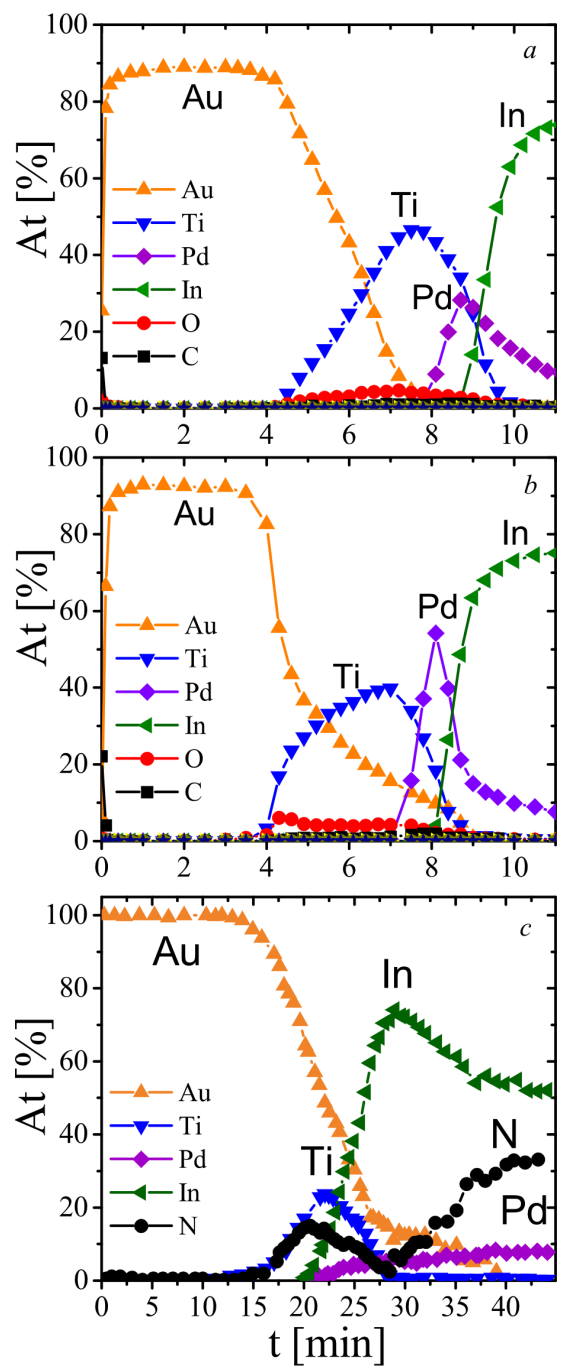

Fig. 2. Profiles of the distribution of layer components under the metallization conducted before RTA: sample A $(a)$, sample $\mathrm{B}(b)$, and sample $\mathrm{C}(c)$

screening potential which exists near edges of metal shunts with a relatively small radius $(V \propto E / r, E$ is the electric field strength, $r$ is the radius of metal shunts) and has the sign opposite to the Schottky potential. Thus, carriers are conducted through the potential energy well at the edge of metal shunts. The basic ideas of this model are shown in Fig. 3. By combining both mechanisms mentioned above, we can explain the variety of experimental $\rho_{\mathrm{c}}(T)$ behaviors, which were reported by Ref. [18] for ohmic contacts to GaAs, InP, GaN [9] and Si [19].

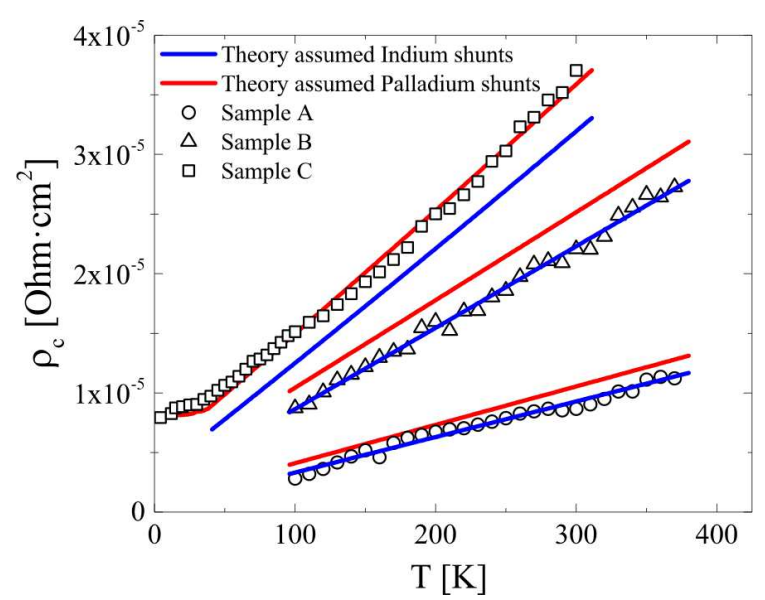

Fig. 3. Experimental (symbols) and theoretical dependences $\rho_{\mathrm{c}}(T)$ in case of current flowing through metal shunts (solid curves)

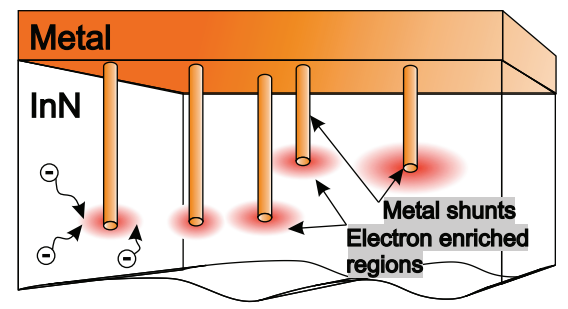

Fig. 4. Basic idea of the mechanism of current transport through metal shunts

For all our samples, we calculated $\rho_{\mathrm{c}}(T)$ using the expressions valid for the thermionic current transport mechanism $\rho_{\text {te }}$ in case of degenerate semiconductors [4]:

$\rho_{\mathrm{te}}=\frac{k}{q A\left(m / m_{0}\right) T \ln \left[1+\exp \left(z+y_{c 0}\right)\right]}$,

where $k$ is the Boltzmann constant, $q$ is the elementary charge, $A$ is the Richardson constant, $m$ is the effective electron mass, $m_{0}$ is the free electron mass, $y_{c} 0$ is the non-dimensional contact potential (normalized to $k T$ ) and $z=E_{\mathrm{F}} / k T$ is the dimensionless Fermi energy. Taking into account that not the whole contact area is involved in the current transport through shunts, we obtain the expression for $\rho_{\mathrm{tw}}$ :

$\rho_{\mathrm{tw}}=\frac{\rho_{\mathrm{te}}}{\pi L_{\mathrm{D}}^{2} N_{\mathrm{D}}}$

where $N_{\mathrm{D}}$ is the effective density of conducting dislocations, and $L_{\mathrm{D}}$ is the Debye screening length. Since, in the case of a degenerate semiconductor, all metal

ISSN 2071-0194. Ukr. J. Phys. 2019. Vol. 64, No. 1 
shunts' resistances $\rho_{\mathrm{sh}}$ are connected in series to $\rho_{\mathrm{tw}}$, the total resistance of an ohmic contact in the semiconductor with high dislocation density can be written as

$\rho_{\mathrm{c}}=\rho_{\mathrm{tw}}+\rho_{\mathrm{sh}}$,

where $\rho_{\mathrm{sh}}=\rho_{0}(T) d_{\mathrm{D}} / \pi r^{2} N_{\mathrm{D}}$ is the temperature dependence of the metal shunt resistivity, $\rho_{0}(T)$ is the temperature-dependent metal resistivity that penetrates into dislocations, $d_{\mathrm{D}}$ is the depth of the metal penetration into a dislocation (shunt length), and $r$ is the shunt radius.

In addition, we consider the temperature dependence of the contact metal resistance (for all our samples, it was palladium, $\mathrm{Pd}$ ) in the contact resistivity modeling. The $\mathrm{Pd}$ resistance behaves itself in the following way [20]: at the zero-point, a resistance is equal to the residual resistance as for a typical metal. At low nonzero temperatures, the resistance increases proportionally to $T^{5}$ due to the electron scattering by phonons. At higher temperatures, there appears a transition region, where the resistance is proportional to $T^{n}$, and $n$ is decreased rapidly, as the temperature grows. In the last region, where $n=1$ at $T \geqslant T_{\mathrm{D}}\left(T_{\mathrm{D}}=274 \mathrm{~K}\right.$ is the Debye temperature of $\mathrm{Pd})$, the metal resistance increases linearly with the temperature.

However, for samples A and B, the best agreement between experimental data and the theory for $\rho_{\mathrm{c}}(T)$ was achieved with the assumption that indium penetrates dislocations and forms metal shunts. This estimation well agrees with our structural investigation, where the Auger profiling showed the indium accumulation in the interface. In contrast to palladium, indium has a significantly lower Debye temperature $\left(T_{\mathrm{D}}=85 \mathrm{~K}\right)$ [21]. Thus, there is a difference in the temperature dependences of the metal resistivities. The pure indium is superconductive below the transition temperature close to $3.4 \mathrm{~K}$. For temperatures below $10 \mathrm{~K}$, the In resistance is proportional to $T^{5}$. A linear dependence appears for temperatures above $40 \mathrm{~K}$. For samples $\mathrm{A}$ and $\mathrm{B}$, we expected the indium penetration into dislocations, because both samples were grown with the accumulation of indium on the surface.

The densities of conducting dislocations $N_{\mathrm{D}}$ were extracted from theoretical $\rho_{\mathrm{c}}(T)$ dependences: $2 \times 10^{10}, 9 \times 10^{9}$, and $5 \times 10^{9} \mathrm{~cm}^{-2}$ for $\mathrm{A}, \mathrm{B}$, and
C samples, respectively. These values are close to experimental results, which were measured by HRXRD (see Tabl. 2). The obtained results confirmed the association of dislocations with the current transport mechanism through metal shunts.

\section{Conclusion}

We have reported about the fabrication of lowresistivity $\mathrm{Pd} / \mathrm{Ti} / \mathrm{Au}$ ohmic contacts to $\mathrm{n}^{+}-\mathrm{InN}$ as a material promising for high-frequency electronics. The ability of the formation of low-resistivity $\left(4.20 \pm 2.67 \times 10^{-6} \mathrm{Ohm} \cdot \mathrm{cm}^{2}\right)$ ohmic contacts with indium nitride with the $2 \times 10^{18} \mathrm{~cm}^{-3}$ doping level is demonstrated in the single technological process of magnetron sputtering with the in-situ thermal annealing.

The additional rapid thermal annealing was used as a method of reduction of the $\rho_{\mathrm{c}}$ mean value and its dispersion that was confirmed by statistical methods. The statistical analysis allowed us to define the optimal parameters of thermal treatments and to significantly reduce the contact resistivity from $(1.18 \pm 1.34) \times 10^{-3} \mathrm{Ohm} \cdot \mathrm{cm}^{2}$ to $(4.46 \pm 2.03) \times$ $\times 10^{-5} \mathrm{Ohm} \cdot \mathrm{cm}^{2}$ for the $4 \times 10^{19} \mathrm{~cm}^{-3}$ doping level and from $(2.99 \pm 1.41) \times 10^{-4} \mathrm{Ohm} \cdot \mathrm{cm}^{2}$ to $(1.96 \pm$ $\pm 0.47) \times 10^{-5} \mathrm{Ohm} \cdot \mathrm{cm}^{2}$ in case of the $8 \times 10^{18} \mathrm{~cm}^{-3}$ doping level.

For the present samples with strong indium accumulation near the "Me-InN" interface, we achieve a good agreement between experimental data and a proposed theory for the temperature-dependent contact resistivity, when the indium penetrations through dislocations were taken into account. In opposite cases, shunts were formed by the metalpalladium contact.

The association of a thermionic current flow through metal shunts with the conducting dislocations was confirmed in the wide temperature range 4.2-380 K for ohmic contacts to $\mathrm{InN}$ with each of the investigated doping levels. The extracted densities of conducting dislocations are close to the densities of screw and edge dislocations determined by High-Resolution X-Ray Diffraction, which confirms this assumption.

This project was partially supported by the Ukrainian government programs III-4-16 and III-1015, National Science Centre, Poland allocated on the basis of Grant No.2016/22/E/STr/00526, and 
by the Foundation for Polish Science through grants TEAM/2016-3/25, and $M A B / 2018 / 9$ (the latter for "Center for Terahertz Research and Applications (CENTERA)" project, carried out within the "International Research Agendas" programme co-financed by the European Union under the European Regional Development Fund.)

1. T.B. Fehlberg, G.A. Umana-Membreno, B.D. Nener, G. Parish, C. Gallinat, G. Koblmüller et al. Characterisation of multiple carrier transport in indium nitride grown by molecular beam epitaxy. Jap. J. Appl. Phys. 45, 1090 (2006).

2. V.M. Polyakov, F. Schwierz. Low-field electron mobility in wurtzite InN. Appl. Phys. Lett. 88, 032101 (2006).

3. W. Liang, K.T. Tsen, D.K. Ferry, H. Lu, W.J. Schaff. Fieldinduced nonequilibrium electron distribution and electron transport in a high-quality InN thin film grown on GaN. Appl. Phys. Lett. 84, 3681 (2004).

4. F. Marino, N. Faralli, D. Ferry, S. Goodnick, M. Saraniti. Figures of merit in high-frequency and high-power GaN HEMTs. J. Phys.: Conf. Series 012040 (2009).

5. R. Keyes. Figure of merit for semiconductors for high-speed switches. Proc. IEEE 60, 225 (1972).

6. B. Baliga. Semiconductors for high-voltage, vertical channel field-effect transistors. J. Appl. Phys. 53, 1759 (1982).

7. C. Gallinat, G. Koblmüller, F. Wu, J. Speck. Evaluation of threading dislocation densities in In- and $\mathrm{N}$-face $\mathrm{InN}$. J. Appl. Phys. 107, 053517 (2010).

8. Z.C. Feng. III-nitride: Semiconductor Materials (Imperial College Press, 2006).

9. M.S. Shur. Handbook Series on Semiconductor Parameters (World Scientific, 1996), V. 1.

10. V.Y. Davydov, A. Klochikhin, V.V. Emtsev, D. Kurdyukov, S. Ivanov, V. Vekshin, et al. Band gap of hexagonal InN and InGaN alloys. Phys. Stat. Sol. (b) 234, 787 (2002).

11. S.N. Mohammad. Contact mechanisms and design principles for alloyed ohmic contacts to n-GaN. J. Appl. Phys. 95, 7940 (2004)

12. A.V. Sachenko, A.E. Belyaev, N.S. Boltovets, P.N. Brunkov, V.N. Jmerik, S.V. Ivanov, et al. Temperature dependences of the contact resistivity in ohmic contacts to n-InN. Semiconductors 49, 461 (2015).

13. P.O. Sai, N.V. Safriuk, V.V. Shynkarenko. Current transport through ohmic contacts to indium nitride with high defect density. in 2017 IEEE 7th International Conference Nanomaterials: Application $\&$ Properties (NAP) (Zatoka, 2017).

14. P.O. Sai. Ohmic contacts to InN-based materials. Tekhnol. Konstruir. Elektron. Appar., Nos. 4-5, 3 (2016).

15. S. Ivanov, T. Shubina, T. Komissarova, V. Jmerik. Metastable nature of InN and In-rich InGaN alloys. J. Cryst. Growth 403, 83 (2014).

16. T.V. Blank, Y.A. Gol'Dberg. Mechanisms of current flow in metal-semiconductor ohmic contacts. Semiconductors $\mathbf{4 1}$, 1263 (2007).
17. C.-Y. Chang, G.-C. Chi, W.-M. Wang, L.-C. Chen, K.-H. Chen, F. Ren, et al. Transport properties of InN nanowires. Appl. Phys. Lett. 87, 093112 (2005).

18. A.V. Sachenko, A.E. Belyaev, N.S. Boltovets, R.V. Konakova, Y.Y. Kudryk, S.V. Novitskii et al. Mechanism of contact resistance formation in ohmic contacts with high dislocation density. J. Appl. Phys. 111, 083701 (2012).

19. A.V. Sachenko, A.E. Belyaev, N.S. Boltovets, A. Vinogradov, V. Kladko, R.V. Konakova et al. Features of temperature dependence of contact resistivity in ohmic contacts on lapped n-Si. J. Appl. Phys. 112, 063703 (2012).

20. M.P. Malkov, I.B. Danilov, A.G. Zel'dovich, A.B. Fradkov. Handbook of Physical and Technical Fundamentals of Cryogenics (Energiya, 1973) (in Russian).

21. G.K. White, S.B. Woods. Indium resistance thermometer; 4 to 300 K. Rev. Sci. Inst. 28, 638 (1957).

Received 26.11.18

П.О. Сай, Н.В. Сафрюк-Романенко, Д.Б. Бут,

Г. Цивінсъкий, Н.С. Болтовецъ, П.Н. Брунков,

Н.В. Жмерик, С.В.Іванов, В.В. Шинкаренко

ОСОБЛИВОСТІ ФОРМУВАННЯ

ОМІЧНИХ КОНТАКТІВ ДО ${ }^{+}-\mathrm{InN}$

$\mathrm{P}$ е $з$ ю м е

У роботі досліджуються механізми струмоперенесення та формування омічних контактів до $\mathrm{n}^{+}-\mathrm{InN} 3$ рівнями легування $2 \cdot 10^{18}, 8 \cdot 10^{18}$ та $4 \cdot 10^{19} \mathrm{~cm}^{-3}$. Омічні контакти $\mathrm{Pd} / \mathrm{Ti} / \mathrm{Au}$ були сформовані в процесі магнетронного напилення металу при одночасному використанні температурної обробки, що дозволило отримати низький питомий контактний опір $(4,20 \pm 2,67) \cdot 10^{-6} \mathrm{OM} \cdot \mathrm{cm}^{2}$. Для покращення властивостей отриманих омічних контактів підтверджено можливість використання додаткових швидких термічних обробок в інтервалі температур 350-400 ${ }^{\circ} \mathrm{C}$, при цьому оптимальні параметри температурної обробки визначалися за допомогою статистичного аналізу даних. Що стосується встановлення механізму струмоперенесення через інтерфейс "метал-InN", спостерігалося нетипове зростання питомого контактного опору в широкому діапазоні температур 4,2-380 K у випадках усіх досліджених рівнів легування плівок InN. B роботі механізм струмоперенесення пояснюється на основі протікання струму через металеві шунти, спряжені з дислокаціями в плівках InN. Аналітично оцінені значення густини провідних металевих шунтів на основі модельних уявлень добре узгоджуються з експериментальними значеннями густин гвинтових та краєвих дислокацій, експериментально отриманих за допомогою високороздільної рентгенівської дифракції. Крім того, з отриманих температурних залежностей питомого контактного опору зроблено висновки про тип металу, який проникає в дислокації і формує металеві шунти.

ISSN 2071-0194. Ukr. J. Phys. 2019. Vol. 64, No. 1 